\title{
The Christian spirituality of the love of God: Conceptual and experiential perspectives emanating from the Gospel of John
}

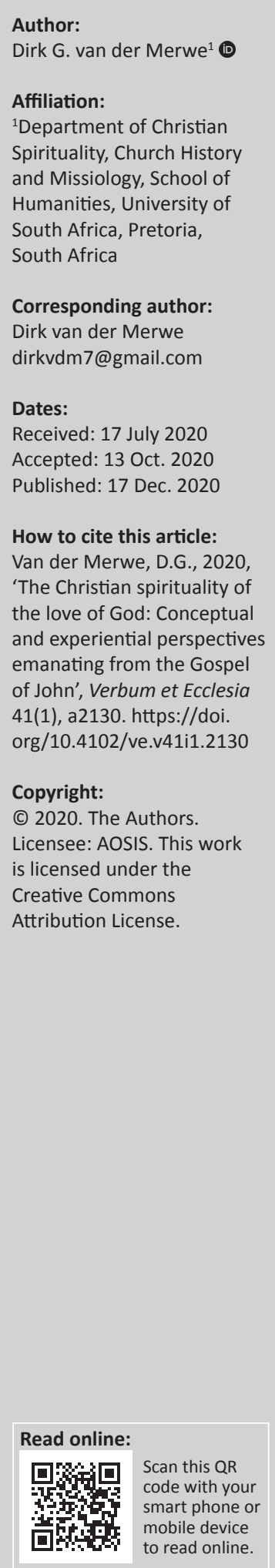

Christians will never be able to fully grasp the identity and character of God. The Bible, despite acknowledging its divine inspiration, cannot fully communicate and explain the attributes or qualities of a God nobody has ever seen (Jn 1:18; 1 Jn 4:12, cf. 4:20). Christians do believe in the love, forgiveness and grace/mercy of God, but will never comprehend it completely; although, we still need to continuously investigate it. The objective of this study, from the perspective of the Gospel of John, was to investigate the concept of God's transcendent love and how God can immanently be experienced as a God of love. Firstly, the article constructs a Johannine picture (concept) of love between the Father and the Son. Secondly, it points out how the love of God is foundationally linked to and 'experienced' of the familia Dei.

Intradisciplinary and/or interdisciplinary implications: The article explores one of the qualities (attributes) of God, namely, the love of God as referred to in the Gospel of John. The exploration is carried out from two perspectives: God's love within the divine being and love of creation. It relates to biblical, systematic and practical theology and also has some implications for missiology.

Keywords: Christians; God; inspiration; qualities; investigate; love.

\section{Introduction}

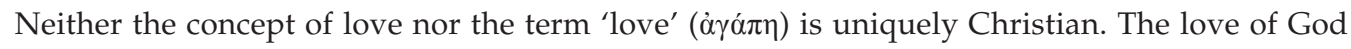
has already been proclaimed in the Old Testament. The Jewish tradition often highlights the abundant and special love of God towards the righteous or Israel. Biblical teachings about the covenant prompted this Jewish tradition (Dt 7:7, 13; 10:15; 23:5; 33:3; Is 63:9; Hs 11:1). Therefore, Isaiah could refer to the restoration of Israel after judgement because of God's special love for Israel (Is 43:4; 63:9; Keener 2005 [2003]:568).

Probably, the clearest expression in the Bible of the loving character of God occurs in 1 John, which contains the statement that God is love $(1 \mathrm{Jn} 4: 8,16)$. This focuses attention to the essential character of love in God to the extent that love can be regarded as a summary of how God approaches people. This love approach should be distinguished from human love. It is God who loves and who initiates love, not humans (1 Jn 4:10, 19). John is overwhelmed by the

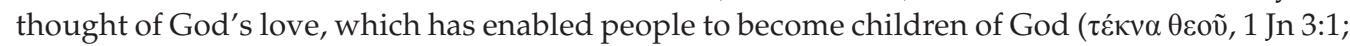
also cf. Jn 1:12). Moreover, if people are to love one another, God's love must be the source (1 Jn 4:7). In fact, those who do not show love to those in need are closing their hearts to the abiding presence of God's love (1 Jn 3:17).

From the Gospel of John, it is definitely clear that the Evangelist, when referring to God's love, does not explain an ontological characteristic of God, a quality locked up in God self. Actually, it may be questioned whether such an abstract form of love is conceivable, as love must have an object. The fact that so much is made of the Father's love for the Son in John's gospel is a strong indication that already within the Godhead God's love has an object. Whilst the New Testament is mainly concerned with humans as the object of God's love, Guthrie (1981:105) pays special attention to the love relation between the Father and the Son in the Gospel of John. The love of the Father can only be understood and only make sense in the event of Jesus' incarnation, crucifixion, resurrection and ascension.

The first reference and expression of God's love in the Gospel of John occur in John 3:16. God

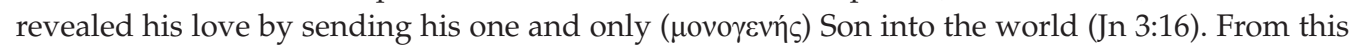
text, we can firstly deduce that Jesus Christ is the full expression of God's love. Secondly, 
God's love is a life-giving love. Before any person had become a Christian, he or she was dead in his or her sins, but through faith in Jesus as the Son of God, humans receive the authority to become the children of God (1:12). The objective of this study, from the perspective of the Gospel of John, investigates how God has revealed his love and how he can be experienced as a God of love. Firstly, the study constructs a Johannine picture (concept) of love between the Father and the Son. Secondly, it points out how the 'lived experience' of the love of God is foundationally linked to the familia Dei and to the mutual love between God, Jesus and Jesus' followers.

\section{The love of God in John: A concept}

This section firstly points out how the Evangelist reflects on the unity between the Father and the Son to contextualise the nature and existence of the love of God. This constitutes an example of what this love conceptually is and how this love of God can be experienced within the familia Dei to serve as a witness to the world. Secondly, this immanent love and unity between the Father and the Son will be examined. Throughout John, the following texts refer to the love of the Father for the Son ( $\dot{\alpha} \gamma \alpha \pi \alpha ́ \omega, 3: 35 ; 10: 17 ; 15: 9 ; 17: 23,24,26 ; \varphi \imath \lambda \dot{\varepsilon} \omega, 5: 20)$ and the Son's love for the Father ( $\alpha \gamma \alpha \pi \alpha \dot{\alpha} \omega, 14: 31) .{ }^{1}$

\section{The mutuality of love and unity in the Gospel of John}

This section primarily focusses on John 17:20-23 to reflect on the unity between the Father, Son and indirectly with a brief reference to the unity between the children of God with the Father and Son. It is axiomatic that love creates unity and that unity can induce love. Therefore, it can be deduced that love and unity are the two sides of a coin. They complement one another. In John 17:20-23, an extended parallelism that occurs in these verses verifies the above reasoning. This reasoning is further confirmed in John 17:24, 26 and 15:9-17 where Jesus refers to the same love that exists between the Father, himself, and his followers.

The following is an extended parallelism (Figure 1) constructed from John 17:20-23 to indicate how important the Evangelist regards the concept of unity between the Father, Son and God's children for the comprehension of the love of God. This parallelism is founded on the 'grammatical structure, the theological content as well as the rhetorical argument' (Van Der Merwe 2017a:5). More parallels occur also in 'words, phrases and prepositional structures'. The repetition ${ }^{2}$ in this parallel is used by the Evangelist for emphasis and to expound the unity theme, which constitutes the medium for love in the Gospel of John (cf. Van Der Merwe 2017a:5) which is evident from John 15:9-17.

1.The love of God/the Father for the world occurs in $3: 16$ (áparaw and 16:27 $(\varphi \iota \lambda \varepsilon \dot{\varepsilon} \omega)$. See Varghese (2009:14-15); also Shin (2019:145-147) for thorough reference to all the 'love' texts in John.

2.Participation or engagement is often enhanced by repeating words, principles and concepts. The reader engages the created images and dialectic embedded in the concepts. The reat rhetoric of the text. Yoder points out, from a didactic perspective, that the value of repetition has long been recognised as an effective means to clarify, emphasise and recapitulate, more value (2005:174). According to her, repetition "principally serves as a means to "interpellate" readers; that is, to call on times again to take up a particular subject position' (2005:175)

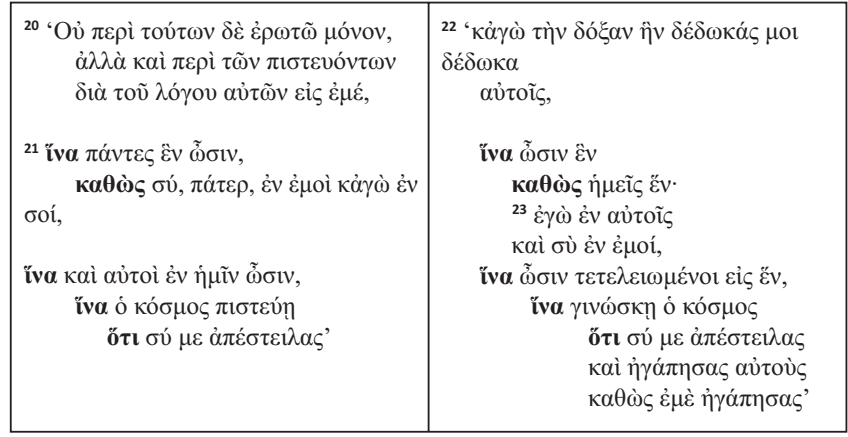

Source: Van Der Merwe, D.G., 1996, 'Discipleship in the Fourth Gospel', Unpublished doctoral thesis, University of Pretoria, Pretoria

FIGURE 1: A paralellism stressing the unity between God, Jesus and the disciples.

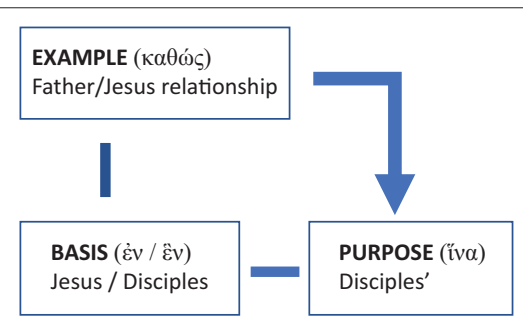

Source: Van Der Merwe, D.G., 1996, 'Discipleship in the Fourth Gospel', Unpublished doctora thesis, University of Pretoria, Pretoria

FIGURE 2: Three interactive levels of unity.

The first cluster of verses (17:20-21) denotes the mutual immanence of the Father and Jesus (17:21) and consequently (iv $\alpha$ ) also denotes the disciples to be 'in' Jesus and the Father (17:21). The second cluster ${ }^{3}$ of verses (17:22-23) refers to the

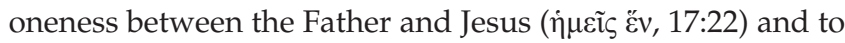

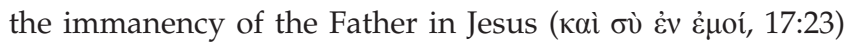
and consequently (ivo) that the disciples may be completely one. The disciples are said to be in the Father and Jesus in

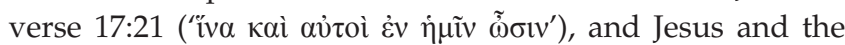

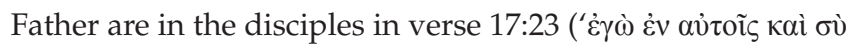

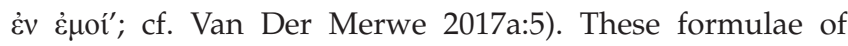
immanence explain how the love in the Godhead and between Jesus and his disciples and mutual love amongst the disciples corporately is constituted and consequently evolved into the disciples' experience of divine love. ${ }^{4}$ Beasley-Murray (1999:302) interprets this unity between Jesus' disciples as mutual participation in 'that unity within the Godhead'.

The three interactive levels as shown in Figure 2 of the relationship emanate from Figure 1.

Figure 2 indicates that the unity and implied love $\mathrm{e}^{5}$ between

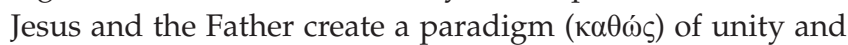
love that should exist between Jesus and his disciples and amongst the disciples communally. The unity and love reality (Jn 15:1-17) between Jesus and his disciples should constitute

3.The variations in the second cluster of texts offer new perspectives. This is evident

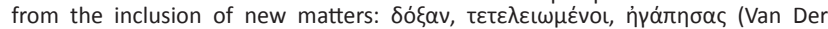
Merwe 2017a:5).

4.See Moltmann (2008:372-378) for an excellent discussion on trinitarian perichoresis, perichoretic community and perichoretic unity.

5.Although there is no reference to love in these texts, love is implied as a result of the two references to love $(17: 24,26)$ between the Father and the Son and John 15 where the immanence of love between the Father, Son and disciples is described. 
the basis $(\dot{\varepsilon} v / \ddot{\varepsilon} v)$ for the disciples' love and unity as the fundamental objectives (iv $\alpha$ ) of love and unity in the Christian community. Jesus endeavours here to emphasise the existence of unity amongst his disciples. He parallelises their unity with the unity existing between the Father and himself. These disciples must also realise that their unity with Jesus ${ }^{6}$ and amongst themselves can only be achieved through their love for one another. This is specifically evident from John 13-15. The disciples' unity is only complete ( $\tau \varepsilon \tau \varepsilon \lambda \varepsilon 1 \omega \mu \varepsilon \dot{v o l})$ when

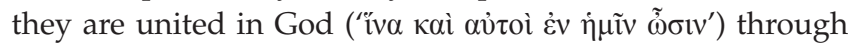
their love for one another. Then their unity reflects the love of God (15:9-10) and becomes the love of God experiential by both - those who receive love and those who show love. Ridderbos (1997) is convinced that the prescribed unity by the Evangelist is:

$[T]$ he great object that Jesus aimed at during his life on earth and now also desires from the Father for the future of the Christian communion: 'in order that they may be all in one ${ }^{7}$ even as we are one'. (p. 559)

All this constitutes the context for what follows now.

\section{The love and unity between the Father and the Son}

The noun 'Father' ( $\left.\pi \alpha \tau \tau^{\prime}\right)$ appears to be the most familiar metaphoric depiction of God in the Gospel of John. It appears nearly 120 times in comparison to the 108 times of the

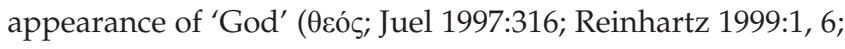
Thompson 1999:24). All appearances are in the singular form. Davies (1992:120) identifies that the noun 'Father' expresses a relation. In the Gospel of John, it specifically refers to the relation between the Father and Jesus (and believers referred to as the children of God, 1:13). Consequently, such a relation makes God knowledgeable and explicitly experiential. ${ }^{8}$ God is distinctively the Father of Jesus who is the Son. Almost all the assertions about God as Father incorporate the function and identity of the Son vice versa. Hence, assertions about the Father are assertions about the Son - to declare the Son involves declaring the Father (Thompson 2014:155). God is exclusively characterised in relationship to Jesus; he is then presented as Father and Jesus as Son (Juel 1997:317).

In the prologue (Jn 1:18), God is referred to as the Father of

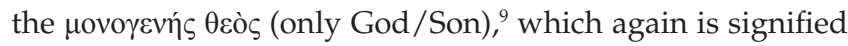

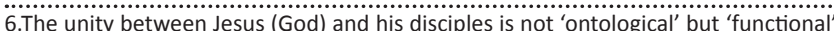
This unity is constituted by God's love and comprises obedience (say and do, will of God), glorification, 'abiding in' and laying down one's life for other and to die in God), glorif
oneself.

7.The phrase 'in order that they may all be one' occurs in 17:11, 21, 22 and 23.

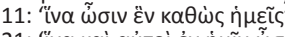

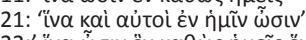

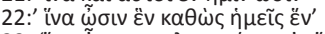

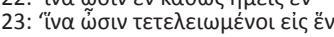

8.On the physical level, Jesus embodies God's love for the world by feeding the hungry $(6: 5-16)$, healing the sick $(4: 46-54 ; 5: 2-9 ; 9: 1-7)$ and giving money to the needy (13:29; Shin 2019:146)

9. Robertson maintains that the way in which Jesus is 'Son' of God is different from the way in which we can become 'children of God' (Jn 1:12): Jesus' relationship with God 'stands apart' (Robertson 2011:325). The referch to Jesus as 'o 'stands apart' (Robertson 2011:325). The reference to Jesus as 'only Son' in the Gospe of John claims that Jesus has a unique intimacy and unity with God. Therefore, he could be 'speaking God's words...doing God's work...and sharing in God's glory" (Edwards 2003:96; cf. Jn 17:1-8). Jesus' intimate relation with God demonstrates the unity of the 'the Father' and 'the Son'. Jesus claims that he has 'seen the Father'
(Jn 6:46); and later asserts that 'just as the Father knows me... I know the Father' as Jesus Christ in John 1:17. Twice (Jn 1:14, 18; cf. also

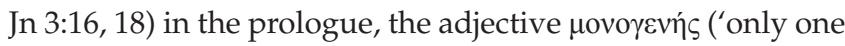
of its kind, one and only, unique' according to ed. Danker 2000:658) climaxes Jesus as the only Son of the Father. Throughout the Gospel of John, Jesus refers to God as Father. Jesus titles God as 'my Father', 'the Father' and distinctively as 'the Father who sent me'. Even, in his editorial clarifications, the Evangelist denotes God to be the Father where Jesus' distinct sonship is brought up. A suitable example is used in John 5:1-18. Here, Jesus decisively calls 'God his own Father, thereby making himself equal to God' (Jn 5:18; cf. Jn 8:27; Thompson 1999:19). The Evangelist also pointed out categorically that Jesus did not do 'the will of God', but the 'will of the Father' (Jn 4:34; 5:30; 6:38; 8:29 and 7:18; 8:50 by implication). In Jesus' dialogues with God, he addresses God as Father. These indications validate why the noun, Father ( $\pi \alpha \dot{\tau} \tau \rho)$, 'has become the most significant term, other than $\theta$ cós (God) itself, to refer to God' (Van Der Merwe 2019:3) - to awake the concept of love. In the Johannine account the Father's love for the Son is the main evidence that love is an essential characteristic of God (Jn 3:35; 5:20; $10: 17 ; 15: 9 ; 16: 27 ; 17: 23 f$.$) . Jesus was deeply conscious of the$ Father's love for him as the foundation stone and pattern of God's love for people (17:23).

The Father's love is not directed to the Father self, but always to other (cf. Shin 2019:146) and lies on two levels - love within the trinity and love towards God's creation in which humans are situated. The love of the Father is central in the Father's relation with the Son. This is evident from John 17:24, ' $[y]$ ou loved Me before the foundation of the world'. This love was at work before the incarnation. ${ }^{10}$ It also fits the relationship of the risen and exalted Jesus to God, as the Gospel says that he is now 'in the bosom of the Father' (1:18). The image is like that of a banquet where people recline around a table. The one who receives special favour lies with his head on the chest of his father who is the host. The Gospel uses this familiar image to depict the Father's love for the Son in a manner and idiom that can be understood to some extent by human beings. At the same time, it emphasises the unique character of this relationship. The Father loves the Son in an idiosyncratic way and this has implications for understanding Jesus' mission and ministry (Keener 2005 [2003]:583).

The authority the Father gives to the Son also expresses his love; and the Son uses this authority to convey love. The Son experiences the love of the Father in the responsibilities the Father gave him as well as the power to execute them. The Gospel says that ' $[t]$ he Father loves the Son and has given all things into His hand' (3:35), 'and shows Him all things (Jn 10.15). Nobody can know God without recognising the identity of Jesus: 'If you knew me', Jesus once said, 'you would know my Father also' (Jn 8:19). Jesus is the ultimate revealer of God, the one who is 'close to the Father's heart, who has made him known' (Jn 1:18). The revealing of God's inner being is regarded by the writer of John as the primary reason for Jesus' incarnation (Jn 1:18). Jesus' very consciousness is 'dominated by the consciousness of God' (Robertson 2011:328).

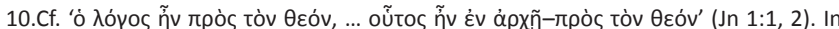
John 17:24, the Evangelist refers to the Father's love for the Son prior to the

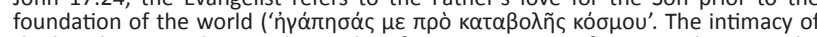
the love between them is also evident from verse 1:18, referring to the Son to be 'in the bosom of the Father' (cf. Koester 2008:49). 
that He Himself does' (5:20; cf. 5:27; 17:2). According to John 3:35, Jesus is certainly the special object of the Father's love. The immense love of the Father for the Son later (17:23) constitutes the Father's love for Jesus' disciples (Keener 2005 [2003]:583). Love is what binds the Father to the Son ${ }^{11}$; and this love is what the Son extends to others. Although the occurrence of intimacy and feeling is attached to love and understands the Evangelist love primarily is a 'bond of commitment' (Koester 2008:49) - 'I have glorified You on the earth. I have finished the work which You have given Me to do' (17:4). There is a resemblance between the love between the Father and the Son. If the Father loves the Son (3:35), it is also true that the Son loves the Father (14:31).

From the Gospel, it became evident that the most radical expression of love is Jesus' crucifixion when he lays down his life to communicate God's love to the world. The crucifixion fractures and reconstitutes the familiar patterns of fatherly love. At one level, the crucifixion is utterly inexplicable on the basis of love. Ordinarily, a father who loved his son would do everything (Koester 2008:49) possible to protect the child from harm. No loving father would allow his son to be treated this way. Yet, God is no ordinary Father and Jesus is no ordinary Son. John finds that in the end, the only thing that explains the inexplicable is love. If God truly loves the world and the Son, then the only way to bring the world back to relationship is by communicating love to it. Moreover, God does this in the crucifixion. The Son is able to bring love into the world because he receives love from his Father (3:35; 10:17). The Son is also willing to bring love into the world because he himself loves the Father $(14: 31 ; 15: 9-10)$. Love is what the Father and Son share to constitute the unity between them and this love has been given to humans through the life and crucifixion of Jesus. The reason is that the love that comes from God makes it possible for people to relate to Father and Son and to become part of a community that is shaped by their love in 17:23-26' (Koester 2008:50).

\section{The love of God in John: A 'lived experience'}

\section{Spirituality and mindset: A 'lived experience' of God's love}

The title of this article starts with the phrase 'The Christian spirituality of the love of God'. Owing to a plethora of definitions, it is necessary to define how the notion, 'Christian spirituality', is used in this article. The definitions of three influential scholars in Christian spirituality will be consulted to define a working definition for this study. Philip Sheldrake (2000:40) defines [Christian] spirituality as 'a conscious relationship with God, in Jesus Christ, through the indwelling of the Spirit and in the context of the community of believers'. For Sandra Schneiders (2000:254), it refers to 'the experience of consciously striving to integrate one's life, in terms not of isolation and self-absorption, but of self-transcendence toward the ultimate value one perceives'. ... 'Spirituality, then, as a lived experience, is by definition determined by the

\footnotetext{
11.Although we can talk and refer to the love and unity between the Father and the Son, it still remains a mystery.
}

particular ultimate value within the horizon of which the life project is pursued'. For Kees Waaijman (2002:312), spirituality refers to 'the divine-human relational process of transformation'. ${ }^{12}$

Against the background of these three related definitions of Christian spirituality, I have drawn up a working definition of spirituality for the purpose of this article. Spirituality has been used to refer to 'living a life of transformation and selftranscendence that resonates with the lived experiences of the divine'. This definition entails two features: 'a lived experience of God in a divine-human relationship' and 'living a life of transformation and self-transcendence that resonates with the lived experiences of God in the believer's life'. Spirituality then becomes a matter of 'lived experiences' the 'lived experiences' of God's love in this context. Describing God's love should not be a matter of theory only but should also focus on the 'lived experiences of the love of God in everyday life'; it is, in fact, a 'lived experience' of God self (God's immanence and God's transcendence) that will transform the person's life.

The 'lived experiences' of the love of God requires a specific mindset for any awareness of divine presence or experiencing divine involvement. The believer must continuously be attentive to experience divine involvement. This will consequently result in that believers reaching out to God through prayer, obedience and devotion. This can materialise formally or informally. Formally, in prayer, or by showing love to others. Any practise of intentional engagement can reveal the presence of God to fellow believers. It can also happen informally. Believers can just become aware that something happened and respond by saying: 'did not our heart burn within us' (Lk 24;32, cf. Adams 2016:276). Believers should regard their relationship with God as a partnership that can cause the greatest excitement when experiencing God's love and involvement in their lives (cf. Adams 2016:278).

In conclusion, distinguishing the love activities of God in this world should not be only a matter of observation or perception but also requires a discernment of eyes of faith (Brümmer 2011:156). It must create a consciousness to become aware to see, hear and experience God's involvement in one's life. It requires a specific attitude of continuous enquiring about divine involvement in one's life. If not, a person can miss such involvement.

\section{The familia Dei and 'lived experience' of the love of God}

\section{The familia Dei}

In early Christianity, authors made use of the 'most intimate social phenomenon' in ancient times, 'the family' as a metaphor for describing the existential reality of being, of love or any form of Christian living (cf. Van Der Watt 1999:494). These authors employed this language of kinship 12.Cf. also the work of McGrath (1999:2-5); Principe (2000:43-60); Perrin (2007:31-32). See Sheldrake (2007) for A brief history of spirituality. 
and applied it to describe the relation between them and their readers in relation to the God they worshipped. They spoke about God, talked to God and experience this divine being within the human idiom. ${ }^{13}$ This involves the typical structures and features of Mediterranean family life and the numerous modes of family featuring (Esler 2000:167).

In the Gospel of John, it is evident how the Evangelist applies a 'coherent network of metaphors, related to the social reality of first-century family life' (cf. Lassen 1997:103; ed. Moxnes 1997; Van Der Watt 1999:491) to explain the most essential Christian concepts, identity and ethical conduct. The Evangelist integrated conventional customs from everyday family life. He applied them to the community activities and ministries to explicate what the Christian community life encompasses. This form of application was to 'rhetorically activate the social experiential dynamic of the mutual relatedness between a father and his child in the mind of the first century reader' (Van Der Watt 1992:272-279). ${ }^{14}$

For the Evangelist, the love motif is the fundamental form of existence of the Christian life in the Johannine community figuring as the familia Dei (Van Der Watt 2000:157, 161-394; also cf. Rusam 1993:105ff; Van Der Merwe 2005:443f.; Van Der Watt 1999:494ff.). Here, God featured as the Father $(1: 14,18)$ and the head, Jesus as the Father's only Son $(1: 14,18 ; 3: 16,18)$ and the believers - God's children ( $\tau \varepsilon ́ \kappa v \alpha$ $\theta \varepsilon$ ov, 1:12). The Holy Spirit (14:26) constituted the Father's presence in the familia Dei. Through these metaphors, the Evangelist brings together the Father, the Son, the Spirit and the believers to compose a familial love relationship (cf. Tollefson 1999:88).

\section{Birth into the familia Dei}

The only manner to gain access to the familia Dei is through a new birth being begotten by God (1:12; born of the Spirit, 3:3-8). Becoming children of God means sharing the same Father with Jesus (20:17) and experiencing the same divine love. Only the revealers from above could truly induct them into the heavenly realm (3:13-18). To become children of God entails the reception of the divine nature or character of which Jesus is the perfect image (Keener 2005 [2003]:403). When a person believes in Jesus (1:12), he or she has been born into the familia Dei by God (1:13). In 3:3-13, the Evangelist elaborates and explains this birth from God in more detail. This birth transforms people to become children of God. New birth is more than a metaphor of social conversion from one group to another; although it includes that it is, in fact, an image of absolute transformation (Keener 2005 [2003]:552), which enables the newborn to experience God's love, God's presence and God's involvement in everyday life.

The phrases given in Figure 3 have been used by the Evangelist to refer to this new birth into the familia Dei from different perspectives.

\section{In fact, this is how God, I believe, has revealed Godself in antiquity to humans.}

14.See Varghese (2009:30-32) for imagery on love in the Gospel of John. He deals with this under the imagery of 'bridegroom-bride', 'friendship' and 'covenant'.

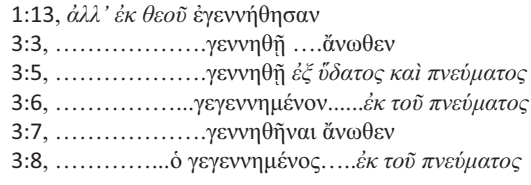

Source: Van Der Merwe, D.G., 1996, 'Discipleship in the Fourth Gospel', Unpublished doctoral thesis, University of Pretoria, Pretoria

FIGURE 3: New birth from different perspectives.

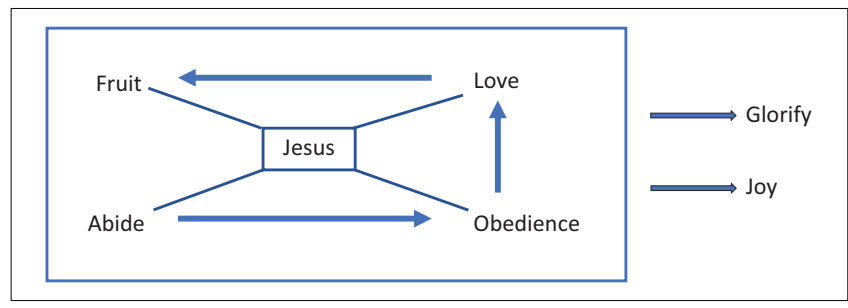

Source: Van Der Merwe, D.G., 1996, 'Discipleship in the Fourth Gospel', Unpublished doctoral thesis, University of Pretoria, Pretoria

FIGURE 4: Life in the family.

The Gospel of John presents divine childhood always as a new birth 'of God', 'the Spirit' or 'from above' (cf. vs. 13; 3:3f.). This shows that it is not a natural quality that every human being has as a creature of God. It is the gift that is given, through love only to those who believe in the Word (Ridderbos 1997:46). This new birth into the familia Dei was made possible by means of God's love for the world (3:16) through the incarnation (1:14), crucifixion and resurrection (19 \& 20) of Jesus, the Son of God and the purifying work of the Spirit (16:8). This 'birth from God' is essential for believers to become aware and experience God's love involvement in their every-day life.

\section{Life in the familia Dei}

John 15:1-17 provides a brief orientation about life in the familia Dei. ${ }^{15}$ Life in the Johannine familia Dei revolves around the person and life of Jesus Christ ${ }^{16}$ (Varghese 2009:347). The pronouns for Jesus in the primary phrases 'abide in me' (15:4) and 'obey my commandments' (15:10) underline this point. Throughout this pericope (Jn 15:1-17), Jesus speaks about himself in the first person. Also, the consistent repetition of the axiom, ' $\mu \varepsilon^{\prime} v \alpha \tau \varepsilon \dot{\varepsilon} v \dot{\varepsilon} \mu o^{\prime}$, the recurrent use of the pronoun $\dot{\varepsilon} \mu$ oí and other expressions emphasise the centrality of Jesus. Although all these components are connected to Jesus, are they also complementarily connected to one another? Their accomplishment within this family will lead to the glorification of God and the experience of joy amongst God's children. According to John 15:1-17, Figure 4 illustrates the experiential principal components of life in the familia Dei.

These components will now be discussed in their relationship to God's love.

15.The theme of bearing fruit saturates the whole pericope, giving it a pragmatic thrust (Varghese 2009:350).

16.Jesus was deeply conscious of the Father's love for him as the foundation stone and pattern of God's love for people (17:23). It is integral to the teaching of Jesus that for man, the most desirable thing is to be the object of God's love (Jn 14:21, 23; Guthrie 1981:104). 


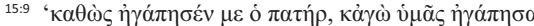

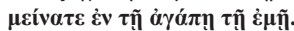

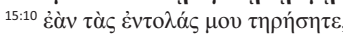

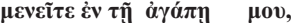

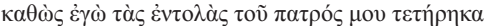

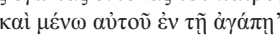

Source: Van Der Merwe, D.G., 1996, 'Discipleship in the Fourth Gospel', Unpublished doctoral thesis, University of Pretoria, Pretoria

FIGURE 5: Love constitutes obedience.

Abide in Jesus: The disciples' obedience to the commandments of Jesus reflects the effect of their love for Jesus $(14: 15,21,23)$. Jesus stresses this crucial fact in 15:9-10 (Figure 5). These two verses are complete and chiastically composed. Its point of departure and point of return indicate the love of the Father. These two $\kappa \alpha \theta \dot{c} \varsigma$-clauses are arranged chiastically with the admonishment to abide in Jesus' love in the centre, revolving around obedience to the commandment of Jesus.

The appeal is this chiasm is to give depth to the admonishment: ' $\mu \varepsilon \dot{i} v \alpha \tau \varepsilon \dot{\varepsilon} v \dot{\varepsilon} \mu o_{i}$ '. The emphasis in this chiasm is obedience. Jesus emphasises his example of obedience to be an example

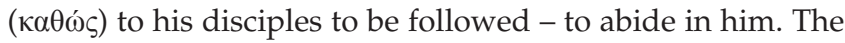
love relation between the Son and the Father is principally sustained by the unconditional obedience of the Son to the Father (Shin 2019:147).

Those who will abide in Jesus will be labelled as disciples of Jesus, as a designation of their new identity in Jesus. This reciprocal indwelling will cause an austere conversion. 'To abide' $(\mu \varepsilon \dot{v} \omega)$ will then become a fundamental activity for experiencing the love of God and for being obedient. ${ }^{17}$ This will cause the followers of Jesus to mature over a length of time into a new community of love and friendship. In such an environment, 'to abide' is then to be openly interconnected to the conduct of obedience and the love of Jesus. The following two expressions form a parallelism to explain what 'abiding in Jesus' means (cf. Van Der Merwe 1996:443):

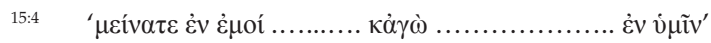

$$
\begin{aligned}
& \text { 15:7 ' }
\end{aligned}
$$

This parallelism explains that the constitution and maintenance of the disciples' mutual indwelling relationship with Jesus is constituted by their abiding $(\mu \varepsilon \dot{v} \omega)$ in the words of Jesus. The words of Jesus would have a purifying effect on them (15:4). Therefore, they should constantly abide (nurtured) in them (15:7). Then in verse 15:9, Jesus

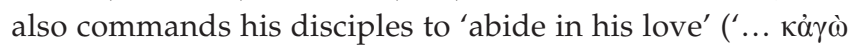

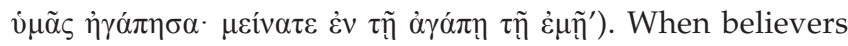
dwell in the words (15:7) and love (15:9) of Jesus, it constitutes a lasting transformation of the manner of life in the community. Their behaviour had to resound Jesus' new love commandment (Jn 13:34; 15:12-17; Stander 2017:166; Van Der Merwe 2017b:8-9). John 17:20-23 provides the theological underpinnings for such a union between the

17.In verse 9 , Jesus implies what it means to abide in him it means to abide in his love (see also 15:7); to continue to have fellowship with him; and to love (and obey) him, similarly as he loves and obeys the Father (15:10; Peterson 2015:24). See also John 15:4-7, 9-10, 16. disciples and Jesus. The mutual indwelling of the Father and Son is the source and standard of Christ's mutual indwelling in believers. John 15 applies the union to the obedience and love life of believers (Peterson 2013:24-25). ${ }^{18}$

Obedience and the love commandment: Love and obedience characterise life in the familia Dei. A valuation of Jesus' love command (15:9-10) denotes that 'obedience evolves out of love and reciprocally love out of obedience' (cf. Barrett 1978:476). Jesus brought his disciples into the unity and love of the Father-Son relationship (Köstenberger 1998:189). He was endorsed and sent by the Father to accomplish this distinctive task on behalf of the Father; hence, 'the one who (Thompson 2014:158) obeys the Son is the one who works in full harmony with the Father' (2014:159). ${ }^{19}$ The implication is that the love, existent from the beginning (cf. Jn 1:1) 'between God and the Word, between the Father and the Son', emanated in the human sphere (Moloney 2013:37-70; cf. Keener 2005 [2003]:1064). Therefore, the words of Jesus 'that the love with which You loved Me may be in them, and I in them' (Jn 17:26).

In the literary context of the Son of Man (Jn 3:14) being 'lifted up' in crucifixion, the aorist है $\delta \omega \kappa \varepsilon v$ in John 3:16 clearly refers to Jesus' death on the cross. ${ }^{20}$ This passage defines the crucifixion as the ultimate expression of divine love for humanity (cf. Rom 5:5-8) ${ }^{21}$ as well as the ultimate expression of Jesus' obedience to the Father. The reference in John 3:16 '[ $f$ ]or God so loved the world' is a qualitative reference to God's love rather than quantitative expression. The adverb Ovi $\omega \varsigma$ in John 3:16 means, ' $[t]$ his is how God loves the world'. This God's love is sensible from the incarnation (" $\delta \omega \kappa \varepsilon v)$ as well as the crucifixion ( $\check{\delta} \delta \kappa \varepsilon v)$. Both the incarnation and cross are the ultimate expression of God's love. Nowhere in this Gospel does God say, 'I love you;' rather, he demonstrates his (Keener 2005 [2003]:566) love for humanity by selfsacrifice $(13: 34 ; 14: 31)$; the culmination of his obedience to the

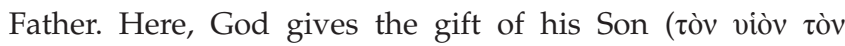

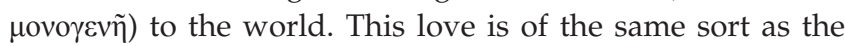
Father's (Keener 2005 [2003]:567) love for the Son (3:35; 15:9; $17: 23)$. This act of love is exemplified on a narrative level in Jesus' love for his friends. ${ }^{22} \mathrm{He}$ entered the realm of hostility to bring them life $(11: 5,7-8)$ by means of the cross $(13: 34)$. It

18.See Peterson for a thorough discussion on the mutual indwelling between the Father and Jesus and Jesus and the disciples (2015:25-27): Jesus the Bread of Life in John 6:32-35, 48-58; Mutual Indwelling of the Father and the Son in John 10:37-38; Mutual Indwelling of the Father and the Son, and the Son and Believers in John 14:8-11, 20, 23; Jesus the Vine, Believers the Branches in John 15:1-17; Mutual Indwelling of the Father and the Son, and of the Son and Believers in John

19.Jesus refers to this mutual love between the disciples in chapters 13 and 14 .

20.The Evangelist stresses the significance of Jesus's incarnation for union with him. John 6 refers on six occasions to Jesus, the bread of life, who came 'from heaven' $(6: 32,33,38,50,51,58)$ and four occasions to the Father who 'sent' $\operatorname{him}(6: 38,39$, $44,57)$. The incarnation is indispensable for the atonement and resurrection of the Son of God and for sinners to be united with him. It was imperative for Jesus to become one of us that we could be united with him. For Jesus's words: '[w] hoever feeds on my flesh and drinks my blood abides in me, and I in him' (v. 56), for this feeding and drinking to occur, God had to become a man. It is axiomatic: no incarnation and no union with Christ (Peterson 2015:15).

21.Both aorists 'loved' and 'gave' in John 3:16 'refer to the supreme act of love' (Brown 1975:1, 133).

22.In his feet washing of the disciples, Jesus (the Son) expressed his love as a self-giving service (Jn 13:1-5; see also Jn 3:16). 
also postulates the example of self-sacrificial love believers had to make for one another $(13: 34-35 ; 15: 12 ; 1$ Jn 3:16; 4:11, 19). This immense love of the Father and Son was already perceived in early Christianity ( $\mathrm{Rm}$ 8:37; Gl 2:20; Eph 2:4; $5: 2,25 ; 2$ Th 2:16) was unquestionably also cherished in the community of Johannine believers (1 Jn 3:16; 4:10, 19; $\operatorname{Rv} 1: 5 ; 3: 9)$. The depiction of divine love is distinctively expressed in early Christianity in terms of self-sacrificing, which is well developed and explained in the Gospel of John (cf. Keener 2005 [2003]:568). Therefore, God demands the same practical demonstration of love from his children $(14: 15,21-24 ; 21: 15-17) .^{23}$

God's love culminated in the crucifixion (17:1) where Jesus ( $\mu$ ovo $\gamma \varepsilon v \operatorname{lm} \theta \varepsilon \varepsilon 0,1: 18$ ) declared ( $\dot{\varepsilon} 1: 18) \dot{\varepsilon} 1: 18 \alpha \tau \mathrm{o}, 1: 18$ ) the love of the Father. The love that is shared between the Father and Son comprises a love that immanently unites them. In the Farewell Discourses, Jesus articulates why he has proclaimed the Father - he wanted (asking the Father, Jn 17) his disciples to be drawn into the same relationship with God he has had at all times.

The two expressions given in Figure 6 construct a parallelism, which expresses the intimate relationship between the Father, Jesus and the disciples.

According to this analysis, the nature of love is at the beginning parallel or equivalent to the love at the end. This designates the representative flow of this love. This implies that the Son allocates the love that emanates from the Father to the Son to the disciples; and it is expected of each disciple to express this love mutually. The love of the Father for Jesus constitutes the example ( $\alpha \theta \omega \dot{\varsigma} \varsigma, 15: 9$; also cf. Figure 2) of Jesus' love for his disciples. The Son, therefore, loves his disciples with the same divine love as the Father loves him (Brown 1972:663). The mutual love between Jesus and his disciples constitutes the basis of the disciples' mutual love for one another. In the same sense, the disciples must love one another. The tendency here is that love is transferred beyond borders. Within the community of the disciples, their mutual love is a group countenance - the identity of disciples is determined by and becomes evident from their mutual love relationship (cf. Van Der Merwe 1996:446).

Similarly, the obedient love relations of the disciples should expose their love for their master (and the Father). The maxim, ' $[i] f$ you love me, you will keep my commandments' (Jn 14:15; cf. Jn 14:21), relates to '[ $t$ ]hose who love me will keep my word' (Jn 14:23) and constitutes the following parallelism:

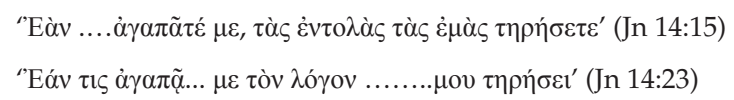

With regard to the interpretation of this parallelism, two assumptions can be made: (1) Jesus sets an example: '[I] do as the Father has commanded me' (Jn 14:31). His identity as God is revealed here through his devoted relationship and 23. Love was certainly not simply a matter of feelings (see Malina \& Rohrbaugh 1998:87).

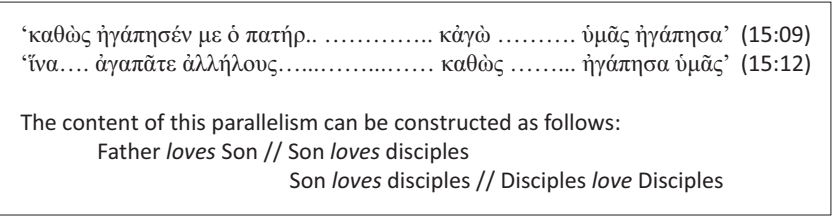

Source: Van Der Merwe, D.G., 1996, 'Discipleship in the Fourth Gospel', Unpublished doctoral thesis, University of Pretoria, Pretoria

FIGURE 6: The disciples' experience of the love of the Father.

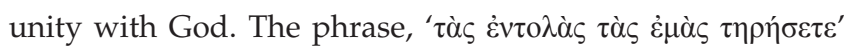
('you will keep my commandments', Jn 14:15), is a designation of their unity and attachment with Jesus. (2) All this denotes that the love of Jesus and his disciples will be equal to the love of the Father. This infers an obedience from the disciples to be equivalent to the obedience of Jesus to the commandments of the Father. The love of the disciples has to reverberate Jesus' love because the love of God defines the quality of this love. This implies that the love of Jesus' behaviour (Van Der Merwe 1996:448; Van Der Watt 1992:83) will epitomise their unity. According to Van Der Watt (1992:86), the obedience of Jesus to the will of the Father $(4: 34 ; 5: 30 ; 8: 38 ; 8: 29)$ has then become his will. Consequently, his will has become similar to the Father's will. If this reasoning is true, then it denotes that Jesus' commandments to his disciples relate to the Father's will for Jesus. Then, the Father's will for Jesus parallels the Father's will for them.

Any clarification of the presence of love in a person must refer to God as the origin of love (cf Furnish 1972:133). This love of God then is concretely revealed in Jesus. When a person accepts Jesus and his revelation of God faithfully (1:12), the love of God will certainly manifest in him (see 17:23-26; cf. Koester 2008:50). This then implies that the love of the Father and the Son is equivalent to that experienced by the disciples. This love does not refer to love as a personal affection, rather to the existential being of a disciple of Jesus for fellow disciples. It determines the person's entire existence. To abide in love, as demanded by Jesus, means to continue in the love they have received from Jesus, which he again experienced from the Father (cf. Bultmann 1941:416). The disciples of Jesus will experience God and God's love through mutual love for one another. God works through people with people. When a person lives in a close relationship with God, God becomes a bigger reality and is experienced by those who make contact with these people - Jesus and later his disciples.

In conclusion, the Father sets an example of how love should be performed. Analogously, the Son and the disciples have to love. Therefore, the love of Jesus' disciples should not differ from Jesus' love, because the quality of Jesus' love is defined by God's love. This consequently implies that the disciples' love is purely an expression and a manifestation of God's love. Their conduct must equate to the conduct of Jesus in particular situations (Van Der Watt 1992:83) in order to bear much fruit.

Bearing much fruit: In verse 15:8, Jesus said, ' $[b] \mathrm{y}$ this My Father is glorified, that you bear much fruit'. The bearing of 
fruit lies on two levels ${ }^{24}$ : (1) in the disciples' obedience to love which would foster unity with Jesus and unity amongst themselves ${ }^{25}$ and (2) when their love and unity will influence

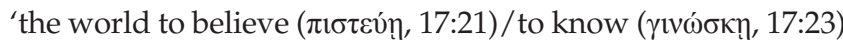
that God has sent his Son into the world'. ${ }^{26}$ The disciples will bear much fruit when they know Jesus intimately (abide, Jn 15), and when they obey Jesus' commands and follow his example (Jn 13). Their relationship with Jesus is to reveal Jesus' relationship with the Father (cf. Köstenberger 1998:191f). The readers of the Gospel of John must realise that any failure to honour the Son implies failure to honour God (5:23; Carson 1991:518). From the reasoning so far, it is evident that the 'intimate union' Jesus promises to the disciples is not a mystical experience. It comprises a relational encounter because of its labelling with the term 'love' (15:9-10; cf. Dodd (1998 [1953]:199-200). Through their obedience to Jesus' commandments, they will demonstrate this love concretely (15:10; cf. 14:15, 21; 15:14) just as Jesus obeyed the Father's command to lay down his life $(10: 18 ; 14: 31)$ to demonstrate the Father's love.

The unity of the Church sought for and achieved by the redemption of the Son of God has brought about that the world may believe and may know'. The Church has to be the embodiment of the redemption and revelation brought by Jesus Christ into the world. The world should not only hear the message that Jesus is the Christ who has brought about redemption for all but also experience that Christ's redemptive revelation has the power to convert sinners into the likeness of God. This would bring about a loving communion and community that the world needs (BeasleyMurray 1999:303). The world will then experience the love of God (3:16).

\section{The effects of consummating the love of God in the familia Dei}

Experiencing joy in abundance: Joy (15:11) relates very well to friendship and love. Jewish teachers also related joy seriously with the keeping of God's commandments, ${ }^{27}$ as stated in John 15:10-12. The phrase 'your joy may be full' ( $\pi \lambda \eta \rho o ́ \omega, 15: 11 ; 16: 24 ; 17: 13 ; 1$ Jn 1:4; 2 Jn 12) was an accustomed form of communication. In early Christianity, joy was related with love to be a result of God's presence (Gal 5:22) and to signify the presence of God's reign (Rm 14:17; Keener 2005 [2003]:1004).

In the Gospel of John, joy seems to be a fundamental motif (especially in 15:11; 17:13). Joy is presented or understood as a result of love. It points out those believers who are

24.Scholars differ in their understanding and interpretation of 'fruit bearing'. See Bolt (1992:13-14) for a brief discussion on this.

25.This statement can be verified from the high occurrence of love terminology in the pericope (15:1-17)

26.The missions of Jesus and his followers culminate in bringing glory to God (Brown 1972:662; Köstenberger 2004:455: Moloney 1998:421). The 'bearing of much fruit' would also have included, laying down their lives (cf. 13:35) in love as Jesus did (cf. 12:24).

27.See Keener (2013:II, 4069) in his commentary on Acts (fn 1254) for an extensive list of Jewish sources.

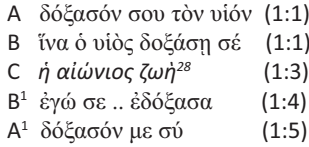

Source: Van Der Merwe, D.G., 2002, 'The glory-motif in John 17:1-5: An exercise in biblica semantics', Verbum et Ecclesia 23(1), 226-249. https://doi.org/10.4102/ve.v23i1.1250 FIGURE 7: Chiasm of the glory-motif.

involved in a close relationship with God in Christ. Complete joy exposes God's presence in Jesus who mediates divine presence amongst people. A joyful life that glorifies God contributes to a continuous devotional life of mutual divine human indwelling. In the Gospel, the 'indwelling of God', 'love', 'obedience', 'bearing of fruit' and 'joy' relate very closely (Stander 2017:166; Van Der Merwe 2017b:9).

To accomplish this joy, Jesus requests his disciples to 'abide in his love' (15:10). Hence, joy results from both love and

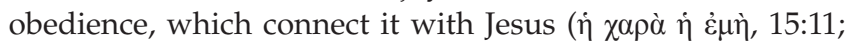
$17: 13)$. Like love, joy is a heavenly quality, as possessed by Jesus (15:11). Therefore, he can award joy to his disciples as a consequence of their obedience (see 15:9; cf. Barrett 1978:509; Carson 1991:546). The joy of the disciples is only mentioned succinctly in 14:28, whilst 15:11 refers emphatically $(\pi \lambda \eta \rho \omega \theta \tilde{\eta}$, aorist, passive and subjunctive) to the joy, which results from communion with Christ. It is remarkably in the Last Discourses $(15: 11 ; 16: 21 \mathrm{f}, 24)$ and the prayer (17:13) where Jesus addresses the new way of life, unity, obedience of abiding in Jesus (15:4), his love (15:9) and his word (8:31) that he refers more frequently to joy.

Glorifying the Father: John 17:1-5 is the culmination of the glorification theme and reasoning in the Gospel of John.

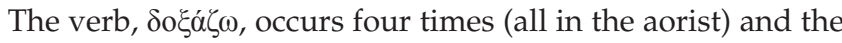
noun, $\delta$ ó $\xi \alpha$, once. The four verbs form a chiastic pattern with 'eternal life' as the centre. This means that the glorification of both the Son and the Father relates with the accomplishment of salvation, which includes the revelation of both Father and Son (1:18). This chiasm emphasises that the essence of salvation is the love of God for the world and is manifested in the crucifixion (and resurrection) of Jesus, the Christ (Figure 7).

'Eternal life' implies here, life in the familia Dei. Verse 3 reads, ' $n$ ] ow this is eternal life: that they may know you, the only true God, and Jesus Christ, whom you have sent'. The main verb here is 'know' ( $\gamma \omega \omega ́ \sigma \kappa \omega$, present, active, subjunctive), which refers to knowledge that advances beyond the intellect to include a loving relationship and communion. The Son's revelation of this causes entrance into a loving fellowship

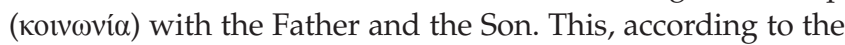
Evangelist, is the core of life (cf. Rv 21:3; 22:3-5; BeasleyMurray 1999:297; Köstenberger 2004:488).

In John 17:1-5, the Evangelist describes how Jesus' love for the Father and the Father's love for the world culminated on

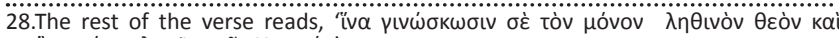

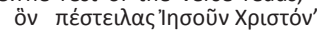


the cross $^{29}$ ('Father, the hour has come. Glorify Your Son, that Your Son also may glorify You', John 17:1, and 'I have glorified You on the earth. I have finished the work which You have given Me to do', 17:4). In the same event, the Father is glorified when His love becomes evident in the glorification of the Son. The Father will be further glorified ${ }^{30}$ when his children love one another and are obedient to Jesus' commands.

\section{Conclusion}

The Gospel of John is probably the book in the New Testament that gives us the best explanation of the love quality of God. Chapters 15 and 17 complement one another with regard to what God's love comprises. The Evangelist succeeds in the presentation of Jesus as not only the personalisation and objectification of God's love but also the content around which the love of God revolves and emanates, for the Son is part of the divine.

The Gospel of John clearly communicates that the familia $D e i$ is the environment in which the children of God should experience this love every day. Experiencing this love of God lies in the 'mutual abiding of Jesus / disciple; the mutual loving of God/Son/other; obedience and the bearing of fruit in abundance'. The unity generated through this love should contribute to be a powerful witness to the world to come to faith in Jesus and to know and to experience that Jesus has been sent by the Father (God) into this world.

In the familia Dei, the love of God is seen and experienced every day when Paul says:

$[L]$ ove suffers long and is kind; love does not envy; love does not parade itself, is not puffed up; does not behave rudely, does not seek its own, is not provoked, thinks no evil; does not rejoice in iniquity, but rejoices in the truth; bears all things, believes all things, hopes all things, endures all things. (1 Cor 13:4-7)

\section{Acknowledgements Competing interests}

The author has declared that no competing interest exists.

\section{Author's contributions}

D.G.V.D.M. is the sole author of this research article.

\section{Ethical consideration}

No ethical clearance was required for this study.

29.Three times (cf. 8:28; $12: 32,34$ ) the Evangelist uses the verb ü $\psi \omega \theta$ ต̃val ('lifted up') to refer to Jesus' crucifixion. his verb has a double meaning, linking Jesus' exaltation with his elevation on a cross (Köstenberger 2004:128; see also Ridderbos 1997:136-37). This implies that Jesus and the Father were glorified in his act of love - his crucifixion.

30.Each glorification reference in these verses has a different meaning. Of relevance here is the third reference to glorification: 'I have brought you glory ( $\delta \circ \xi \alpha \dot{\alpha} \zeta \omega)$ on earth by completing the work you gave me to do. (17:4). Here, $\delta 0 \xi \alpha \zeta \omega$ refers to 'me, and to finish His w' Me, and to finish His work'). In 5:36, the plural 'works' ( $\tau \dot{\alpha} \varepsilon p \gamma \alpha$ ) relate to the diverse works that the Father has given to the Son to accomplish (Beasley-Murray 1999:297) and which he did successfully (17:4).

\section{Funding information}

This research received no specific grant from any funding agency in the public, commercial or not-for-profit sectors.

\section{Data availability statement}

Data sharing is not applicable to this article as no new data were created or analysed in this study.

\section{Disclaimer}

The views and opinions expressed in this article are those of the authors and do not necessarily reflect the official policy or position of any affiliated agency of the authors.

\section{References}

Adams, M.M., 2016, 'Prayer as the "lifeline of theology"', Anglican Theological Review 98(2), 271-283.

Barrett, C.K., 1978, The Gospel according to St John: An introduction with commentary and notes on the Greek text, SPCK, London.

Beasley-Murray, G.R., 1999, John, Word Incorporated, Dallas, TX.

Bolt, P., 1992, 'What fruit does the vine bear? Some pastoral implications of John 15:1-8', The Reformed Theological Review 51(1), 11-19.

Brown, R., 1972, The Gospel according to John, (I-XII, The Anchor Bible), Geoffrey Chapman, Toronto.

Brown, R., 1975, The Gospel according to John, (XIII-XXI, The Anchor Bible), Geoffrey Chapman, Toronto.

Brümmer, V., 2011, Wat doen ons wanneer ons bid?, Ashgate Publishing Limited, London.

Bultmann, R., 1941, Das Evangelium des Johannes, Vandenhoeck und Ruprecht, Göttingen.

Carson, D.A., 1991, The Gospel according to John, W.B. Eerdmans, Grand Rapids, MI.

Danker, F.W. (ed.), 2000, Greek English Lexicon of the new testament and other early Christian literature, 3rd edn., University of Chicago Press, Chicago, IL.

Davies, M., 1992, Rhetoric and reference in the Fourth Gospel, JSNT 69, Sheffield Academic Press, Sheffield.

Dodd, C.H., 1998 [1953], The interpretation of the Fourth Gospel, Cambridge University Press, Cambridge.

Edwards, R.B., 2003, Discovering John: Content, interpretation, reception, SPCK, London.

Esler, P.F., 2000, 'Keeping it in the family: Culture, kinship and identity in 1 Thessalonians and Galatians', in J.W. Van Henten \& A. Brenner (eds.), Families and family relations as represented in Early Judaisms and Early Christianities: Texts and fictions, pp. 145-184, Deo Publishing, Leiden.

Furnish, V.P., 1972, The love command in the New Testament, SCM, London.

Guthrie, D., 1981, New testament theology, Inter-Varsity Press, Downers Grove, IL.

Juel, D.H., 1997, 'The trinity in the new testament', Theology Today 54(3), 312-324. https://doi.org/10.1177/004057369705400303

Keener, C.S., 2005 [2003], The Gospel of John: A commentary, 2 vols., Hendrickson Publishers, Peabody, MA.

Keener, C.S., 2013, Acts. An exegetical commentary, vol. II, Baker Academic, Grand Rapids, MI.

Koester, C.R., 2008, The word of life: A theology of John's gospel, Eerdmans, Grand Rapids, MI.

Köstenberger, A.J., 1998, The missions of Jesus and the disciples according the Fourth Gospel, Eerdmans, Grand Rapids, MI.

Köstenberger, A.J., 2004, John, Baker Academic, Grand Rapids, MI.

Lassen, E.M., 1997, 'The Roman family: Ideal and metaphor,' in H. Moxnes (ed.), Constructing early Christian families: Family as social reality and metaphor, pp. 103-120, Routledge, New York, NY.

Malina, B. \& Rohrbaugh, R.L., 1998, Social-science commentary of the Gospel of John, Fortress Press, Minneapolis, MN

McGrath, A.E., 1999, Christian spirituality: An introduction, Blackwell Publishing, Oxford.

Moloney, F.J., 1998, The Gospel of John, Sacra Pagina Series 4, The Liturgical Press, Collegeville, PA.

Moloney, F., 2013, Love in the Gospel of John: An exegetical, theological and literary study, Baker Academic, Grand Rapids, MI.

Moltmann, J., 2008, 'God in the world - The world in God: Perichoresis in trinity and eschatology', in R. Bauckham \& C. Mosser (eds.), The Gospel of John and Christian theology, pp. 369-381, Eerdmans, Grand Rapids, MI. 
Moxnes, H. (ed.), 1997, Constructing early Christian families: Family as social reality and metaphor, Routledge, London.

Perrin, D.B., 2007, Studying Christian spirituality, Routledge, New York, NY.

Peterson, R.A., 2013, 'Union with Christ in the Gospel of John', Presbyterion 39(1), 9-29.

Principe, W., 2000, 'Toward definig spiritality', in K.J. Collins (ed.), Exploring Christian spirituality: An ecumenical reader, pp. 43-60, Baker Books, Grand Rapids, MI.

Reinhartz, A., 1999, 'Introduction: Father as metaphor in the Fourth Gospel', Semeia 85(1), 1-10.

Ridderbos, H., 1997, The Gospel of John: A theological commentary, Eerdmans, Grand Rapids, MI.

Robertson, S., 2011, 'Sonship in John's Gospel', Asia Journal of Theology 25(2), 315-333.

Rusam, G., 1993, Die gemeinschaft der kinder Gottes: das motiv der Gottes kinderschaft und die gemeinden der Johanneishen brieven, Verlag W. Kohlhammer, Stuttgart.

Sheldrake, P. 2000, 'What is spirituality?', in K.J. Collins (ed.), Exploring Christian spirituality: An ecumenical reader, pp. 21-42, Baker Books, Grand Rapids, MI.

Sheldrake, P., 2007, A brief history of spirituality, Blackwell Publishing, Oxford.

Shin, S., 2019, Ethics in the Gospel of John: Discipleship as moral progress, Brill, Leiden.

Stander, A.J., 2017, 'Menein as key to a mystical reading of John 15', Unpublished doctoral thesis, University of the Free State, Bloemfontein.

Thompson, M.-A., 1999, 'The living Father', in A. Reinhartz (ed.), God the Father in the Gospel of John, Semeia, vol. 85, pp. 19-31, Society of Biblical Literature, Atlanta, GA.

Thompson, M.M., 2014, 'The Gospel of John in early Trinitarian thought: The unity of God in John, Irenaeus and Tertullian', Journal of Early Christian History 4(2), 154-166. https://doi.org/10.1080/2222582X.2014.11877309

Tollefson, K.D., 1999, 'Certainty within the fellowship: Dialectic discourse in 1 John', Biblical Theology Bulletin 29(2), 79-89. https://doi.org/10.1177/0146107999 02900204
Van Der Merwe, D.G., 1996, 'Discipleship in the Fourth Gospel', Unpublished doctoral thesis, University of Pretoria, Pretoria.

Van Der Merwe, D.G, 2002 'The glory-motif in John 17:1-5: An exercise in biblical semantics', Verbum et Ecclesia 23(1), 226-249. https://doi.org/10.4102/ve. v23i1.1250

Van Der Merwe, D.G., 2005 “Understanding "sin" in the Johannine epistles', Verbum et Ecclesia 26(2), 543-570. https://doi.org/10.4102/ve.v26i2.240

Van Der Merwe, D.G., 2017a, 'Conceptualising holiness in the Gospel of John: The mode and objectives of holiness (Part 1)', HTS Theological Studies 73(3), 1-9. https://doi.org/10.4102/hts.v7313.4610

Van Der Merwe, D.G., 2017b, 'Conceptualising holiness in the Gospel of John: The en route to and character of holiness (Part 2)', HTS Theological Studies 73(3), 1-11. https://doi.org/10.4102/hts.v7313.4610

Van der Merwe, D.G., 2019, 'Divine fellowship in the Gospel of John: A Trinitarian spirituality', HTS Theological Studies 75(1), 1-12. https://doi.org/104102.hts. v76i1.5375

Van Der Watt, J.G., 1992, 'Julle moet mekaar liefhê: etiek in die Johannesevangelie', Scriptura S9A, 74-96.

Van Der Watt, J.G., 1999, 'Ethics in first John: A literary and socio-scientific perspective', Catholic Biblical Quarterly 61(4), 491-511.

Van Der Watt, J.G., 2000, The family of the king: Dynamics of metaphor in the Gospe according to John, Brill, Leiden.

Varghese, J., 2009, The imagery of love in the Gospel of John, Gregorian \& Biblical Press, Rome.

Waaijman, K., 2002, Spiritualiteit: vormen, grondslagen, methoden, Peeters, Dudley.

Yoder, C.R., 2005, 'Forming "fearers of Yahweh"', in R.L. Troxel, K.G. Friebel \& D.R. Magary (eds.), Seeking out the wisdom of the ancients: Essays offered to honor Michael V Foxon on the occasion of his sixty-fifth birthday, pp. 167-183, Eisenbrauns, Winona Lake, IN. 